\title{
Melanin and Behaviour of Melanoma-related Cell Lines in the Presence of Ultraviolet B Type Radiation
}

\author{
ZSOLT GYORI ${ }^{1 *}$, MIRCEA BERCEANU ${ }^{2 *}$, ADELINA CHEVERESAN ${ }^{1 *}$, CLAUDIA FARCAS $^{2}$, TIBERIU BRATU ${ }^{1}$, ZORIN CRAINICEANU $^{1}$ \\ ${ }^{1}$ Victor Babes University of Medicine and Pharmacy, Faculty of Medicine, 2 Eftimie Murgu Sq., 300041, Timisoara, Romania \\ 2 Victor Babes University of Medicine and Pharmacy, Faculty of Pharmacy, 2 Eftimie Murgu Sq., 300041, Timisoara, Romania

\begin{abstract}
Melanoma is a malignant disease of the cutaneous organ that shows significant aggression, resistance to treatment and increased mortality. Melanin and B-type ultraviolet radiation are key factors in the appearance and development of melanoma. In this study, the melanocyte and two melanoma tumor cells behaviour was evaluated in the presence of UVB radiation. The results highlighted the significant impairment of melanin-producing malignant cells, COLO-829, at both radiation doses tested.
\end{abstract}

Keywords: melanin, melanoma, UVB, viability, morphology

Melanoma is a malignant skin disease, also known as cancer that rises with the sun. It develops following molecular and biochemical aberrations of melanocytes, is the least common of skin cancers but has the highest mortality rate due to its aggressiveness [1-3], related to pre-existing pathologies in the patient [4]. The different wavelengths of ultraviolet radiation bring distinct responses to the skin. A specific feature of melanoma is the mutational signature induced by UV radiation, present in over $75 \%$ of cases [5]. Radiation that contains both UVA and UVB, in a manner similar to that of solar radiation, stimulates the expression of a few specific melanocytic markers, and increases melanin production. UVA radiation alone does not have this effect; UVB radiation significantly increases skin melanin content and melanogenic enzyme expression, but UVA radiation can also lead to visible skin tanning in the same way as UVB radiation. Both types of radiation lead to distinct damage to skin cells with severe, sometimes fatal consequences [6]. In the case of human skin, keratinocytes make up most of the epithelium, are subjected to keratinization and form the skin's superficial dead layer. After keratinization they are permanently replaced with cells from the basal layer. In the basal layer there are also melanocytes, responsible for the production of melanin pigment that accumulates in melanosomes. Melanosomes are transported to dendrites where they are then transferred to keratinocytes. These two types of cells are responsible, through interactions between them, for epidermal and hair follicles homeostasis [7].

Melanogenesis, the metabolic pathway specific to both healthy and diseased melanocytes is a key factor in the development of melanoma and directly influences the behavior of melanoma cells and their environment [8]. Melanin (fig. 1) has a double action, namely: 1) beneficial - due to its protective role on melanocytes in the case of UVB and oxidative stress, and 2) harmful - due to possible degraded melanogenesis that is responsible for melanoma therapy resistance) $[9,10]$.

In addition, specialty studies highlight the higher radiotherapy sensitivity of amelanotic melanomas compared to melanotic melanomas, also taking into account a higher survival rate for amelanotic ones $[8,10]$.

In the present research, the behaviour of cell lines that have a direct relation with the study of the appearance, development and treatment of melanoma was observed

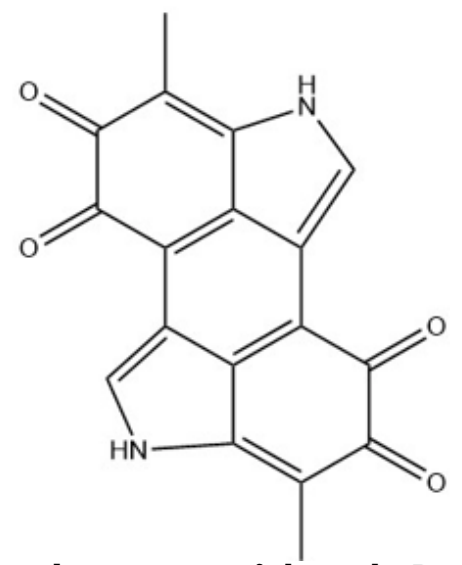

Fig. 1. Melanin chemical structure

in the presence of ultraviolet $B$ type radiation at two different doses. For this purpose were utilized the healthy melanocytes and two type melanin-related human melanoma cells.

\section{Experimental part \\ Materials and methods}

One healthy and two tumor cell lines acquired as frozen items from ATCC were utilized in the current experiment. The healthy cell line was primary human epidermal melanocytes (HEMa - ATCC $®$ PCS-200-013 ${ }^{\mathrm{TM}}$ ), and the tumor cell lines were human melanomas (SK-MEL-3 ATCC $₫$ HTB-69 ${ }^{\mathrm{TM}}$ and COLO-829 - ATCC $®$ CRL-1974 ${ }^{\mathrm{TM}}$ ). The appropriate media necessary for cells cultivation Dermal Cell Basal Medium, Adult Melanocyte Growth Kit, McCoy's 5a Medium Modified, and RPMI-1640 Medium were purchased from ATCC while all the other reagents, like: fetal bovine serum (FBS), penicillin/streptomycin mixture, phosphate-buffered saline (PBS), trypsin/EDTA and Trypan blue were obtained from Sigma Aldrich (Germany). HEMa - primary melanocytes were multiplied in Dermal Cell Basal Medium in which was added with an Adult Melanocyte Growth Kit, $100 \mathrm{U} / \mathrm{mL}$ penicillin and 100 $\mathrm{g} / \mathrm{mL}$ streptomycin mixture, SK-MEL-3 were cultured in McCoy's 5a Medium Modified, supplemented with fetal bovine serum to a final concentration of $15 \%$, and COLO829 were cultured in RPMI-1640 Medium, supplemented with fetal bovine serum to a final concentration of $10 \%$. During cultivation all cells were kept in optimal conditions for propagation -humidified atmosphere with $5 \% \mathrm{CO}_{2}$ at $37^{\circ} \mathrm{C}$ and passaged every $48 \mathrm{~h}$. The cells were counted with 
a Countess II FL Automated Cell Counter device in the presence of Trypan blue.

The UVB irradiation protocol, assumed the use of cells at a confluence of $\min .80-85 \%$ and the main steps were: removal of the medium prior to UVB exposure, washing with PBS, exposure at $312 \mathrm{~nm}$, at two different doses - 30 $\mathrm{mJ} / \mathrm{cm}^{2}$ and $60 \mathrm{~mJ} / \mathrm{cm}^{2}$ with a Biospectra system (Vilber Lourmat, France).

Cell viability was evaluated by the Alamar blue assay: 10,000 cells/200 $\mu \mathrm{L}$ medium/well were seeded in a 96well plate, incubated for $24 \mathrm{~h}$ after UVB exposure and spectrophotometrically analysed at $570 \mathrm{~nm}$ and $600 \mathrm{~nm}$ wavelengths with a xMark ${ }^{T M}$ Microplate Spectrophotometer (BioRad) as previous described [10, 11].

\section{Results and discussions}

UVB irradiation of HEMa, SK-MEL-3 and COLO-829 cells with UVB, at $30 \mathrm{~mJ} / \mathrm{cm}^{2}$ and $60 \mathrm{~mJ} / \mathrm{cm}^{2}$, pointed out a slightly reduction of cells viability at the highest exposure dose as compared to control cells (cells without UVB irradiation) at $24 \mathrm{~h}$ after irradiation. The percentage of viable cells from the experiments conducted on the melanomarelated cell lines are presented in table 1.

Some data presented in literature pointed out a cell viability at $80 \mathrm{~mJ} / \mathrm{cm}^{2}$ insignificant affected at $24 \mathrm{~h}$ after UVB exposure [12]. The damage to melanocytes is due to the fact that they act as defenders of nuclei, keratinocytes and fibroblasts in exposure to ultraviolet radiation and melanin by the photosensitization process is generating reactive oxygen species $[13,14]$.

Regarding morphological changes, after the exposure of melanocytes to UVB, it was observed that the dose of $30 \mathrm{~mJ} / \mathrm{cm}^{2}$ induced minor changes in cell morphology immediately after exposure. Cells returned completely after 24h. After exposure to $60 \mathrm{~mJ} / \mathrm{cm}^{2}$, the cells underwent

\begin{tabular}{|l|l|l|l|}
\hline UVB radiation dose & HEMa - human melanocytes & $\begin{array}{l}\text { SK-MEL-3-human } \\
\text { melanoma }\end{array}$ & $\begin{array}{l}\text { COLO-829-human } \\
\text { melanoma }\end{array}$ \\
\hline & \multicolumn{3}{|c|}{ VIABLE CELLS $\%$ ) } \\
\hline $30 \mathrm{~mJ} / \mathrm{cm}^{2}$ & $89 \pm 0.6$ & $72 \pm 1.1$ & $46 \pm 0.4$ \\
\hline $60 \mathrm{~mJ} / \mathrm{cm}^{2}$ & $60 \pm 1.1$ & $59 \pm 0.9$ & $18 \pm 0.9$ \\
\hline
\end{tabular}
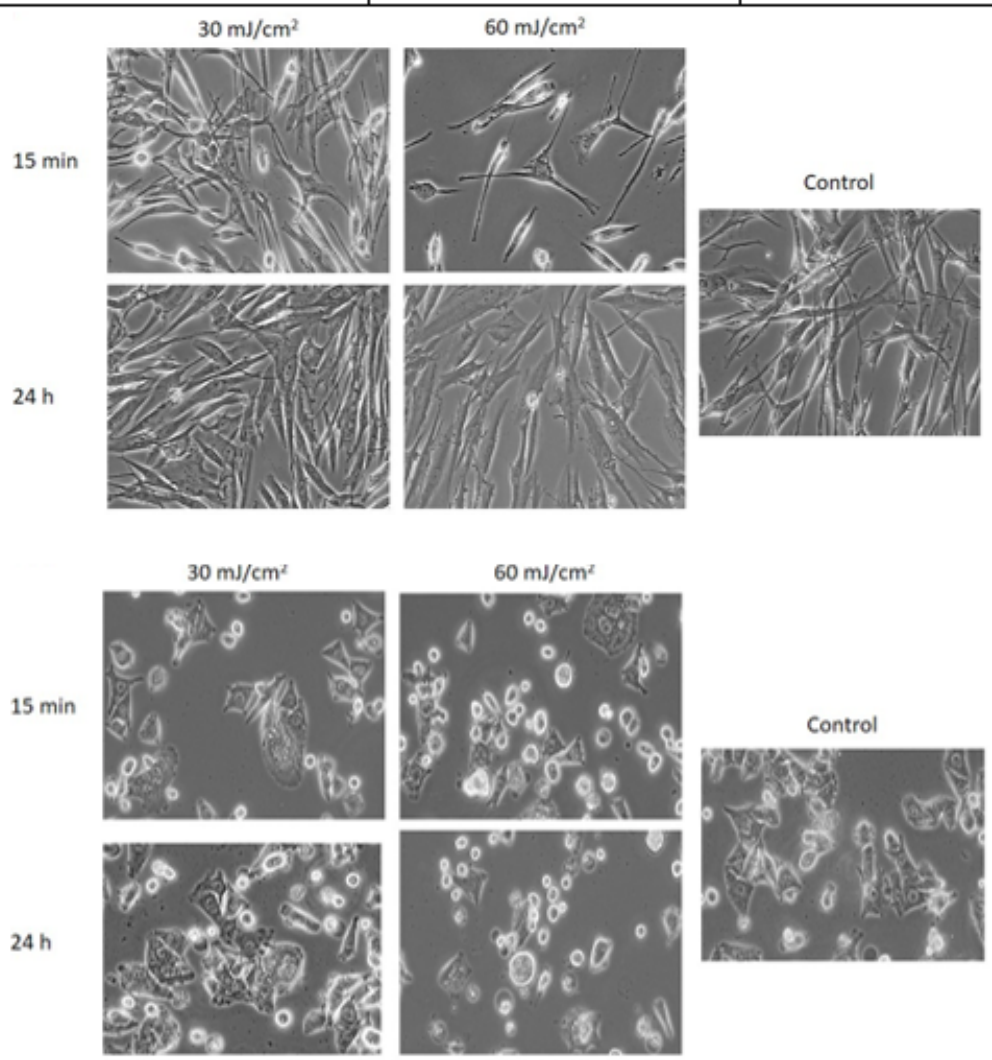

significant morphological changes accompanied by loss of cell confluence but after $24 \mathrm{~h}$ they regained confluency, although some changes in cell cytoskeleton were observed - many cells did not regain their specific form needle-like (fig. 2).

SK-MEL-3 cells were not affected by the exposure of 30 $\mathrm{mJ} / \mathrm{cm}^{2}$, they even expressed proliferative activity 24 hours after exposure (figure 3). The dose of $60 \mathrm{~mJ} / \mathrm{cm}^{2}$ displayed a deleterious effect on SK-MEL-3 cells, a large number of cells being unable to regain activity after 24 hours - many of them being detached from the plate.

UVB treatment had the most detrimental effect on COLO-829 cells. Immediately after exposure, the cells appeared significantly affected after both doses ( 30 and $60 \mathrm{~mJ} / \mathrm{cm}^{2}$ ), but after $24 \mathrm{~h}$ cells treated with the dose of 30 $\mathrm{mJ} / \mathrm{cm}^{2}$ began to regain their specific morphological appearance. The same cannot be said for the cells exposed at a dose of $60 \mathrm{~mJ} / \mathrm{cm}^{2}$, in which case over $90 \%$ of the cells have apoptotic appearance, the cells being not attached to the culture plate (fig. 4).

The multitude of biological and environmental factors that are related to the appearance and development of melanoma denote the need to deepen studies about the role of melanin in the mechanisms involved. Primary epidermal melanocytes (HEMa) have been taken in this study due to the major involvement of melanogenesis in the development of melanoma. It is also known that genetic factors and hormone status play a key role in regulating melanin synthesis [10]. One type of mechanism involved in the protection of melanocytes against UVB radiation or the development of malignanttumors involves the development of melanocytic dendrites as melanin pigment carriers from melanocytic cells to keratinocytes.
Table 1

THE VIABILITY OF CELLS AFTER IRRADIATION WITH $30 \mathrm{~mL} / \mathrm{cm}^{2}$ AND $60 \mathrm{~mL} / \mathrm{cm}^{2}$ UVB COMPARED WITH CONTROL CELLS (UNIRRADIATED CELLS)
Fig. 2. In vitro morphological changes of primary human epidermal melanocytes - HEMa cells in the presence of UVB rays
Fig. 3. In vitro morphological changes of human melanoma - SK-MEL-3 cells in the presence of UVB rays 


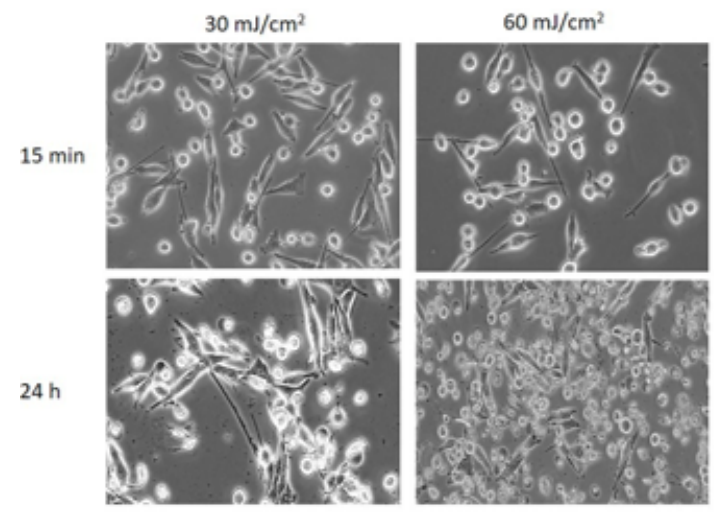

This mechanism has also been met in the case of exposure to melanoma cells in UVB.

SK-MEL-3 cells, in nude mice forms pigmented malignant melanoma, while early passage of COLO-829 cells contain a small percentage of melanin producing cells. Due to these characteristics, it is possible to explain the influence of UVB radiation observed on cells.

\section{Conclusions}

Shortly after exposure to UVB, at two different doses of radiation, the melanocytes are affected, but after 24 hours they are completely recovered. In the case of human melanoma cells, UVB radiation is extremely toxic to melanin producing cells, namely, COLO-829, in a much greater manner than those that do not produce melanin in the culture - SK-MEL-3 - but have the ability to produce pigmented tumors in animal models.

\section{References}

1. CORICOVAC, D., DEHELEAN, C., MOACA, E.A., PINZARU, I., BRATU, T., NAVOLAN, D., BORUGA, O. Int J Mol Sci. 19, 2018, p. 1566.

2. HOLMES, D. Nature 515, 2014, p. S110.

3. AVRAM, S., CORICOVAC, D.-E., PAVEL, I.Z., PINZARU, I., GHIULAI, R., BADERCA, F. et al. Oncol. Rep. 38(1), 2017, p. 89.
4. HORHAT, R.M., VLAICU, B., BAGIU, R., PUTNOKY, S., BAGIU, I., HORHAT, D.I., SZUHANEK, C. et al. Rev. Chim.(Bucharest), 69, no. 6, 2018, p. 1371.

5. VINCENT, K.M., POSTOVIT, L.-M. Oncotarget. 8(6), 2017, p. 10498. 6. CHOI, W., MIYAMURA, Y., WOLBER, R., SMUDA, C., REINHOLD, W., LIU, H. et al. J. Invest. Dermatol. 130(6), 2010, p. 1685.

7. HIROBE, T. Dermatol. Sin. 32(4), 2014, p. 200.

8. SLOMINSKI, A., KIM, T.K., BROZYNA, A.A., J ANJ ETOVIC, Z., BROOKS, D.L., SCHWAB, L.P. et al. Arch. Biochem. Biophys. 563, 2014, p. 79. 9. MADDODI, N., SETALURI, V. Photochem. Photobiol. 84, 2008, p. 528. 10. CORICOVAC, D., FARCAS, C., NICA, C., PINZARU, I., SIMU, S., STOIAN, D., SOICA, C. et al. Int J Mol Sci. 19, 2018, p. 3600.

11. PREDA, M., CHEVERESAN, A., PINZARU, I., DOBRESCU, A., PAVEL, I.Z., VLAIA, V., SISU, E. Rev. Chim. 69(7), 2018, p. 1907.

12. MIZUTANI, Y., HAYASHI, N., KAWASHIMA, M., IMOKAWA, G. Arch. Dermatol. Res. 302, 2010, p. 283.

13. SLOMINSKI, A., TOBIN, D.J., SHIBAHARA, S., WORTSMAN, J. Physiol. Rev. 2004, 84, p. 1155.

14. POLETINI, M.O., DE ASSIS, L.V., MORAES, M.N., CASTRUCCI, A.M. Mol. Cell Biochem.2016, 421, p. 29.

Manuscript received: 18.11 .2018 